\title{
Correction to: IL-1b is a key cytokine that induces trypsin upregulation in the influenza virus-cytokine-trypsin cycle
}

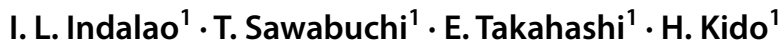

Published online: 28 September 2018

(c) The Author(s) 2018

\section{Correction to: Arch Virol (2017) 162:201-211 https://doi.org/10.1007/s00705-016-3093-3}

The original version of this article unfortunately contained a mistake in the "Enzyme-linked immunosorbent assay (ELISA)" section of "Materials and methods" third paragraph. The corrected paragraph is updated here.

The levels of IL-6, TNF-a and IL-1b, and trypsin were measured using ELISA kits (R\&D Systems for the cytokines and MyBioSource for trypsin) according to the respective protocol provided by the manufacturer.
The original article can be found online at https://doi.org/10.1007/ s00705-016-3093-3.

H. Kido

kido@tokushima-u.ac.jp

1 Division of Enzyme Chemistry, Institute for Enzyme Research, Tokushima University, Tokushima 770-8503, Japan
Open Access This article is distributed under the terms of the Creative Commons Attribution 4.0 International License (http://creativeco mmons.org/licenses/by/4.0/), which permits unrestricted use, distribution, and reproduction in any medium, provided you give appropriate credit to the original author(s) and the source, provide a link to the Creative Commons license, and indicate if changes were made. 